\title{
Zakat Untuk Mengurangi Angka Ketergantungan Ekonomi Dengan Penyaluran Model Usaha Produktif
}

\author{
Mochlasin \\ Institut Agama Islam Negeri Salatiga \\ mochlas_sofyan@yahoo.co.id
}

\begin{abstract}
The discussion in this paper covers: What is the motive for establishing zakat institutions in Pulosari, Jumoyo, Salam, Magelang? How is the collection mechanism? How is the distribution model? This research type was field research with data collection technique through observation, interview and documentation. The result of this research found that the distribution of productive zakat is done in three ways. First, model in kind, that BAZIS manager gave zakat as capital without having to return and without bond, Second, non-financial mudharabah model, the BAZIS manager gives goat breeding, if the goat gives birth to the child a mustahiq right while the indutility is returned to be distributed to other mustahiq. Third, al-qard al-hasan model, amil channeling zakat property in the form of capital to mustahiq with provisions for returning capital.
\end{abstract}

Keywords: Productive zakat, mustahiq, tasharruf

\begin{abstract}
Abstrak
Pembahasan dalam tulisan ini meliputi: Apa motif pendirian lembaga zakat di Pulosari, Jumoyo, Salam, Magelang, Bagaimana mekanisme pengumpulannya, Bagaimana model penyalurannya? Jenis penelitian ini adalab field research dengan tehnik pengumpulan data melalui pengamatan, mewancara dan dokumentasi. Hasil penelitian ini menunjukkan bahwa penyaluran zakat produktif dilakukan dengan tiga cara. Pertama, model in kind, yaitu pengurus BAZIS memberikan zakat sebagai modal tanpa harus mengembalikan serta tanpa ikatan apun. Kedua, model mudharabah non finansial, yaitu pengurus BAZIS memberikan indukan kambing, apabila kambing beranak maka anakkannya menjadi hak mustahiq sedangkan indukannya dikembalikan untuk disalurkan kepada mustahiq lainnya. Ketiga, model al-qard al-hasan, yaitu amil menyalurkan harta zakat dalam bentuk modal kepada mustahiq dengan ketentuan mengembalikan modal.
\end{abstract}

Kata Kunci: Zakat produktif, mustahiq, tasharruf

Permalink/DOI: http://dx.doi.org/10.18326/infsl3v12i1.239-258 


\section{Pendahuluan}

Sebagaimana umumnya terjadi pada negara-negara berkembang, masalah kemiskinan di Indonesia masih menjadi persoalan yang belum terpecahkan secara tuntas meskipun tingkat kemiskinan menurut pemerintah mengalami penurunan. Menurut laporan BPS yang dapat diakses secara daring, memasuki tahun 2017 jumlah penduduk miskin sejumlah sebesar 10,64\% atau sejumlah 27,77 juta jiwa. Angka sebesar itu tentunya mayoritas penduduk muslim, karena mayoritas penduduk Indonesia pemeluk agama Islam. Namun data dan fakta di lapangan menunjukkan bahwa penurunan angka kemiskinan tidak sebanding lurus dengan turunnya angka ketergantungan penduduk. Islam memandang kemiskinan sebagai suatu problematika kehidupan, bahkan kemiskinan dianggap sebagai musibah yang harus dihindari (Qaradhawi, 2002: 16).

Menurut laporan Harian Kompas (2018), pada tahun 2017 rasio ketergantungan penduduk menunjukkan tren membaik meskipun masih cukup tinggi, yaitu sebesar 48,1 persen. Angka itu menunjukkan bahwa setiap 100 orang penduduk usia produktif harus menanggung 48 penduduk tidak produktif. Usia produktif adalah penduduk yang berusia 15-60 tahun. Dengan demikian, semakin tinggi rasio ketergantungan penduduk tidak produktif, maka semakin berat beban yang ditanggung oleh usia produktif. Sebaliknya, rendah rasio ketergantungan maka semakin rendah beban yang ditanggung usia produktif. Jika ketergantungan semakin kecil, maka berpotensi untuk dapat meningkatkan kesejahteraan keluarga yang harus ditanggungnya (Kompas, 9 April 2018). Kondisi demikian akan berdampak positif pada potensi terbebasnya dari lilitan kemiskinan.

Fase baru tentang tafsir masyarakat sebagai civil society, telah melahirkan dukungan yang lebih negara kepada masyarakat, partispasi masyarakat kepada negara dan peran dari masyarakat kepada masyarakat. Dalam arus perubahan hubungan masyarakat dan negara, zakat mendapatkan momentum tafsir baru, meskipun dalam sejarah peradaban Islam zakat telah berfungsi untuk peningkatan kehidupan ekonomi masyarakat (Mochlasin, 2015: 95). Pemerintah melalui Sri Mulyani, dalam sebuah acara acara 2nd 
Annual Islamic Finance Conference di Yogyakarta menyatakan bahwa keuangan syariah dinilai dapat mendorong pencapaian target tujuan pembangunan berkelanjutan 2030 (Sustainable Development Goals). Salah satu tujuan SDGs, yakni pengentasan kemiskinan dan kesenjangan ekonomi. Salah satu cara yang bisa dilakukan yaitu dengan mengelola zakat dengan baik. Menteri Kuangan juga menyinggung tentang pengumpulan dana zakat hingga saat ini masih belum optimal. Saat ini potensi sebenarnya cukup besar yakni sekitar Rp 217 triliun per tahun atau lebih dari 10 persen dari Anggaran Pendapatan dan Belanja Negara (APBN).

Menyikapi masalah kemiskinan ini, masyarakat Dusun Pulosari Desa Jumoyo, Kecamatan Salam, Kabupaten Magelang yang berada di lereng Gunung Merapi mencoba mewujudkan pengelolaan zakat untuk usaha produktif dalam rangka membantu mengentaskan dan mensejahterakan kaum kurang mampu (dhuafa' dan mustad'afin). Dari latar belakang tersebut, maka rumusan masalah dalam tulisan ini adalah: (1) Apa motif pendirian lembaga zakat di Pulosari, Desa Jumoyo, Kecamatan Salam, Kabupaten Magelang?; (2) Bagaimana mekanisme pengumpulan zakat di Pulosari Desa Jumoyo, Kecamatan Salam, Kabupaten Magelang? (3) Bagaimana model penyaluran (tasharruf) zakat di Pulosari Desa Jumoyo, Kecamatan Salam, Kabupaten Magelang untuk mengurangi angka ketergantungan penduduk?

\section{Bonus Demografi dan Rasio Ketergantungan}

Badan Perencanaan Pembangunan Nasional (Bappenas) melaporkan, bahwa penduduk Indonesia pada tahun 2016 mencapai angka 258 juta jiwa, memasuki tahun 2018 dipastikan melebihi jumlah tersebut. Diperkirakan oleh BPS jumlah penduduk Indonesia pada tahun 2035 mendatang mencapai 305,6 juta jiwa dan akan menjadi negara kelima dengan jumlah penduduk terbanyak di dunia. Selama ini Indonesia telah menjadi negara berpenduduk terbanyak di di dunia untuk negara-negara yang berpenduduk muslim. Berdasarkan kelompok umur, kondisi penduduk Indnesia dapat dilihat pada grafik berikut: 


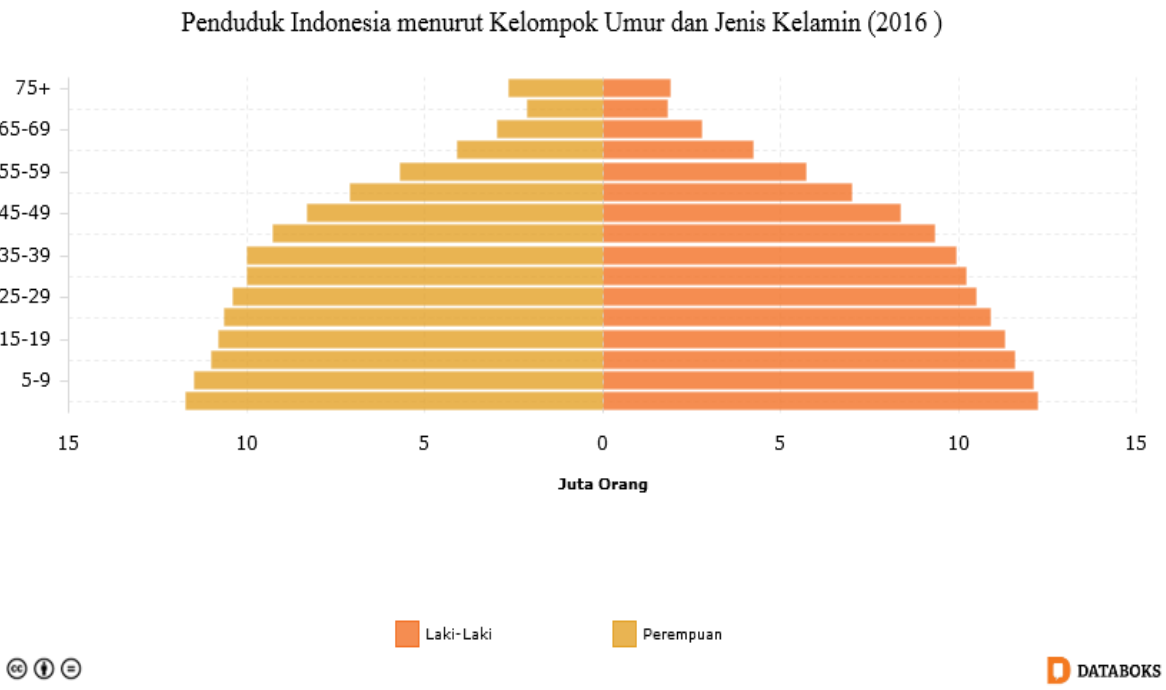

Grafik Penduduk Indonesia Menurut Usia

Dari grafik di atas, menunjukkan usia 5-9 menduduki rangking pertama. Tingginya jumlah penduduk muda berarti meningkatnya biaya yang dibutuhkan untuk memenuhi kebutuhan mereka. Hal itu berakibat pada penghasilan yang didapatkan oleh penduduk produktif harus didistribusikan untuk mengantisipasi kebutuhan tersebut yang menyebabkan lebih rendahnya angka investasi pada aspek-aspek lainnya. Grafik tersebut juga telah menimbulkan fenomena yang disebut "demographic dividend" atau "demographic bonus". Istilah ini menggambarkan jumlah penduduk produktif yang lebih tinggi, sehinnga akan berdampak pada angka produksi yang lebih tinggi dibanding dengan angka konsumsi.

Pembagian berdasarkan produktivitasnya versi BPS, penduduk dapat dibagi menjadi tiga yaitu: (1) penduduk usia nonproduktif yang meliputi penduduk usia muda (0-15 tahun); (2) penduduk usia produktif (15-65 tahun); penduduk tua yaitu usia 65 tahun ke atas. Usia 15-65 disebut sebagai usia produktif karena pendapatan yang diproduksi cenderung lebih tinggi dibandingkan konsumsinya. Adapun disebut nonproduktif karena kecenderungan biaya konsumsi yang lebih tinggi dibanding dengan pendapatannya. 
Berikut grafik besaran rasio ketergantungan pendduduk sampai tahun 2016:

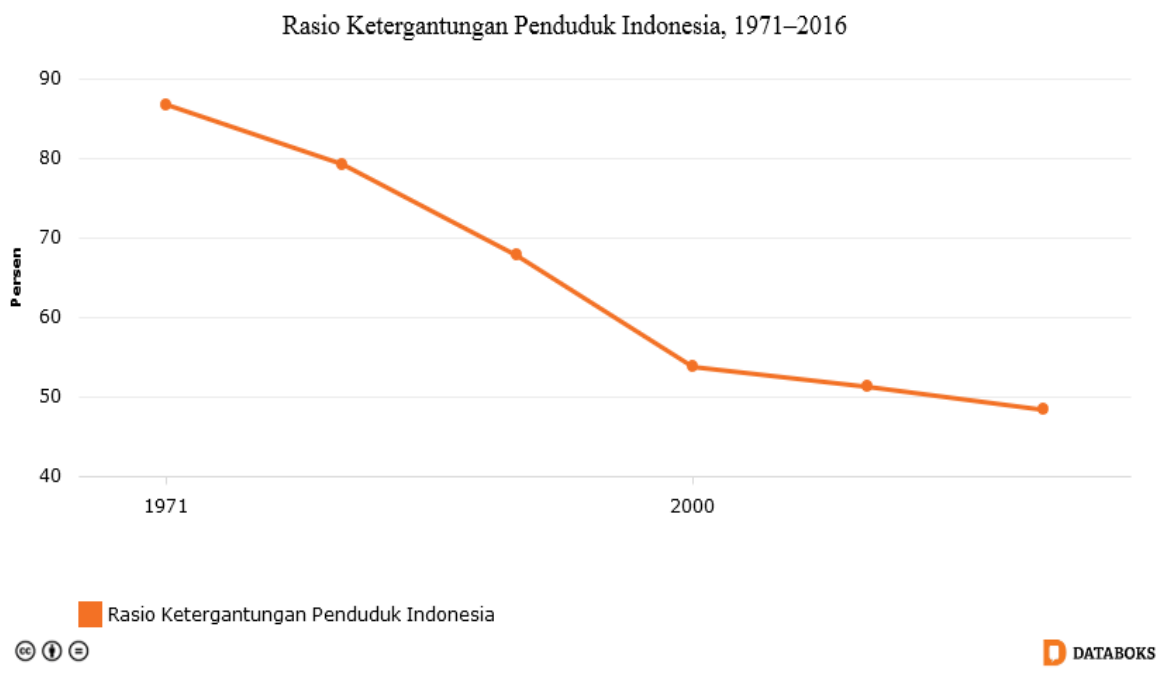

Grafik Rasio Ketergantungan

BPS memproyeksikan rasio ketergantungan pada tahun 2016 telah mencapai angka 48,4, yang berarti setiap 100 orang berumur produktif menanggung penduduk berusia nonproduktif sebanyak 48-49 orang. Dari data statistik menunjukan bahwa rasio ketergantungan terus mengalami tren penurunan, dari angka 86,8 di tahun 1971 dan diproyeksikan hingga 46,9 pada tahun 20282031. Untuk mengurangi angka ketergantungan yang masih cukup tinggi, maka tingkat kemiskinan harus diturunkan. Dua penyebab penurunan kemiskinan sedikit melambat karena tingakat inflasi dan program pengentasan kemiskinan yang tidak berkelanjutan baik bersumber dari APBN maupun lembaga swadaya masyarakat (Kompas, 9/4/2018). Dari sinilah, lembaga filantropi Islam melalui syariat zakat dapat berperan untuk membantu mengurangi angka kemiskinan sehingga angka ketergantungan penduduk juga berkurang. 


\section{Maksimalisasi Potensi Zakat}

Dalam acara 2nd Annual Islamic Finance Conference di Yogyakarta, Menteri Keuangan Sri Mulyani menyatakan bahwa pengumpulan dana zakat hingga saat ini masih belum optimal. Menkeu menilai bahwa potensi zakat cukup besar yakni sekitar Rp 217 triliun per tahun atau lebih dari 10 persen dari Anggaran Pendapatan dan Belanja Negara (APBN). Laporan dari BAZNAS menyebutkan, bahwa selama ini baru sebesar dua persen yang dapat dihimpun dan dikelola. Terdapat beberapa sebab tentang kesenjangan antara yang seharusnya dan senyatanya ini. Setidaknya terdapat tiga hal: (1) pemahaman tentang zakat mal atau zakat profesi masih lemah; (2) masih banyak masyarakat yang membayar zakat melalui keluarga ataupun pengelola zakat informal; (3) pengelolaan zakat yang masih konvensional sehingga trust dari muzakki menurun.

Untuk itulah diperlukan peran dari berbagai pihak, utamanya dari muzakki, mustahiq dan pemerintah. Dar sisi muzakki, peran yang bisa dilakukan adalah memaknai kembali tentang harta-harta yang harus dizakati dengan melihat perkembangan saat ini. Profesi yang mendari ciri ekonomi modern, harus menjadi perhatian lebih dalam memahamkan tentang pentingnya zakat ini. Peran ini juga dapat dilakukan dengan pendataan yang valid daftar muzakki. Pendataan ini penting, karena banyak masyarakat yang levelnya kategori muzakki tetapi belum menunaikan zakat. Maka lembaga pengelola harus lebih proaktif terhadap muzakki yang lalai dalam menjalankan syariatnya.

Peran mustahiq dapat diwujudkan dengan menanamkan kesadaran bahwa suatu saat harus dapat merubah levelnya menjadi muzakki. Kesadaran penting agar grafik mustahiq setiap tahun berkurang seingga ketergantungan terhadap kelompok produktif dapat diurai. Di samping itu, pendataan mustahiq juga sangat diperlukan agar tidak terjadi salah sasaran. Pendataan ini juga berfungsi untuk mengetahui sejauhmana kinerja dari sebuah lembaga zakat dalam rangka menunaikan amanatnya.

Tidak kalah pentingnya adalah peran pemerintah dalam memberikan regulasi terhadap pelaksanaan pengelolaan zakat. 
Sampai saat ini, pemerintah telah mengeluarkan UU Zakat no 23 tahun 2011 ang diikuti PP No. 14 Tahun 2014 yang berisi tentang pengelolaan zakat. Perlu dipahami, bahwa UU tersebut tidak mengatur tentang sanksi bagi pengemplang zakat. Presiden RI juga sangat mendorong pengelolaan zakat dengan mengeluarkan Instruksi Presiden (Inpres) No. 3 Tahun 2014 terkait dengan optimalisasi pengumpulan zakat di lingkungan kementerian/lembaga, BUMN dan BUMD melalui BAZNAS.

Untuk mencagai gagasan pemberdayaan masyarakat yang maksimal melalui zakat, maka perlu peran sinergis antara muzakki, mustabiq, organisasi masyarakat seperti Muhammadiyah, NU, Persis dan lain-lain sebagaimana tergambar dalam bagan berikut:

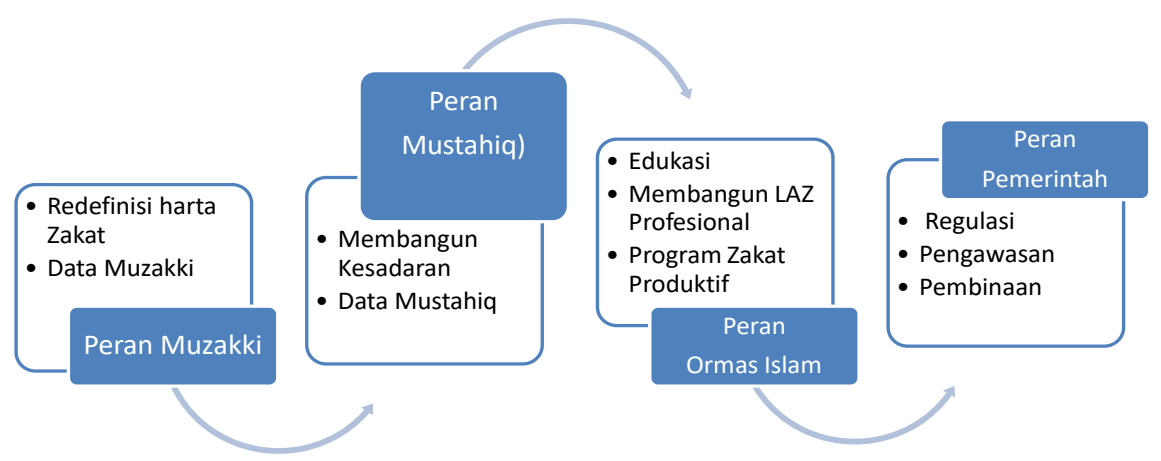

Grafik Optimalisasi Pengelolaan Zakat

\section{Mekanisme Pentasyarufan Zakat Produktif}

Seiring munculnya kesadaran untuk membantu program pengentasan kemiskinan dan didukung oleh SDM yang cukup, memunculkan pengelolaan yang kreatif dan produktif sehingga manfaat zakat lebih meluas. Berikut bagan pergeseran paradigma pentasharufan zakat dari tradisional ke manjerial produktif dilihat dari dampaknya (Mufraini, 2008: 45): 


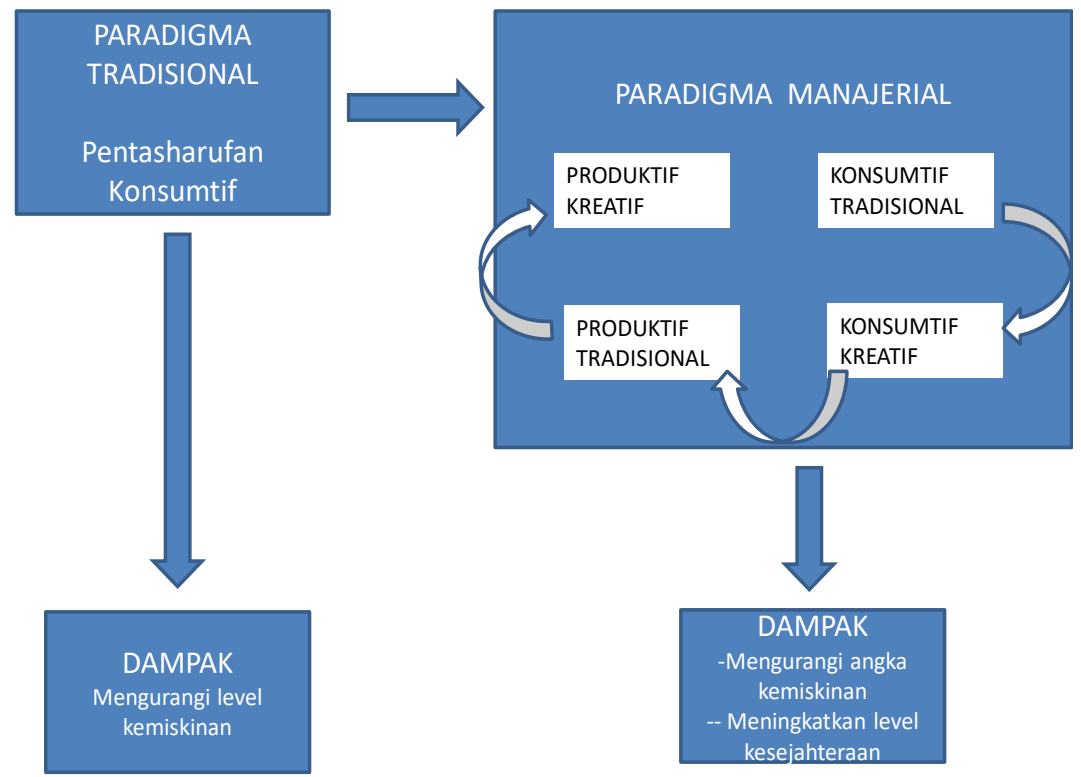

Bagan Ragam Penyaluran Zakat

Dalam penyaluran produktif kreatif, terdapat tiga model inovasi yang dilakukan di beberapa tempat yaitu:

1. Model in kind, yakni dana zakat diberikan dalam bentuk alat-alat produksi yang dibutuhkan oleh mustahiq atau kelompok ekonomi lemah yang ingin berproduksi, baik yang ingin merintis atau mengembangkan usaha yang telah ada (Muharom dalam Muhammad dan Mas'ud, 2005: 123):

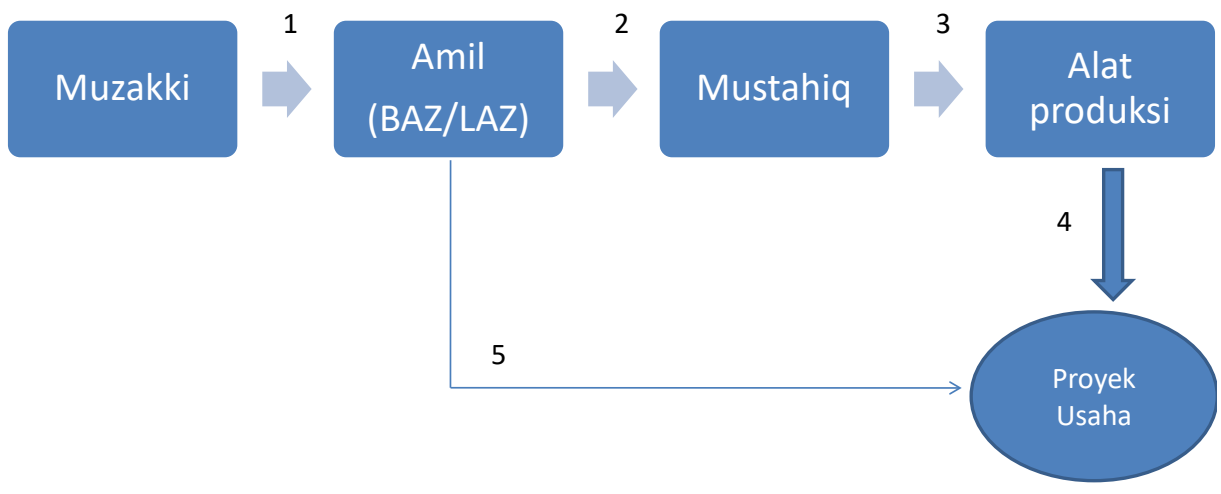

Bagan Model in-Kind 
2. Model al-Qard al-Hasan atau Revolving Fund, yaitu dana yang ditasharufkan kepada melalui amil kepada mustahiq hanya dituntut untuk mengembalikan pinjamannya saja tanpa memberi keuntungan yang diperhitungkan. Dalam model ini muzakki menjadi mitra bagi mustahiq, sehingga diharapkan di masa-masa yang akan datang posisinya beranjak menjadi kelas muzakki. Model ini dapat digambarkan dalam bagan berikut (Muhamad dan Ms'ud, 2005: 124):

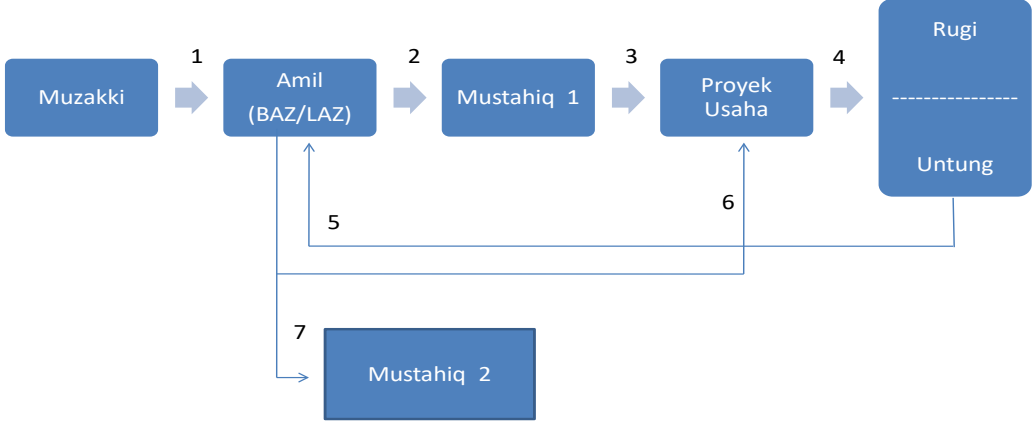

Bagan Revolving Fund

3. Model Mudharabah, amil mentasharufkan harta zakat kepada mustahiq dalam bentuk modal yang harus diperhitungkan sebagai bisnis, di samping mustahiq (mudharib) harus mengembalikan modal juga harus memberikan keuntungan atau bagi hasil kepada amil selaku shahibul mal dengan pembagian keuntungan yang telah disepakati. Model ini dapat digambarkan sebagai berikut (Mufraini, 2006: 167):

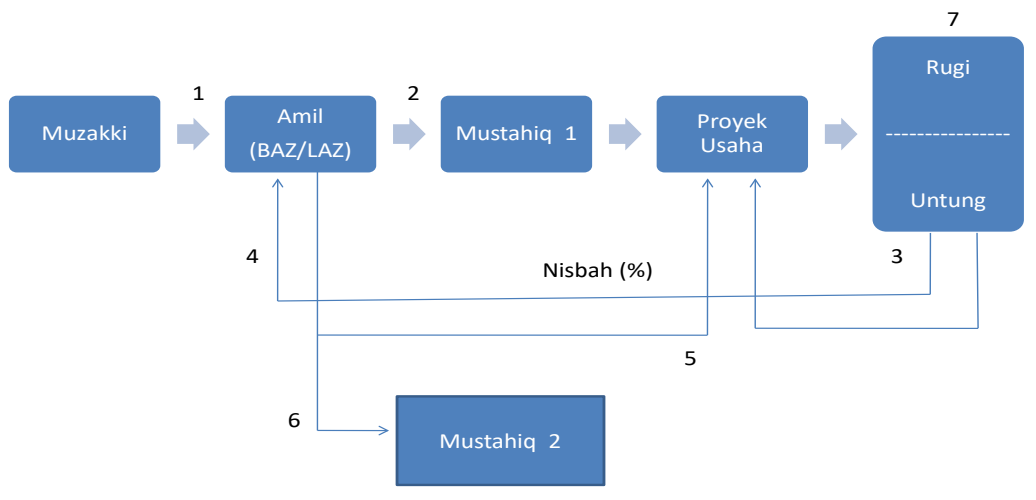

Bagan Model Mudharabah 


\section{Metode Penelitian}

Jenis penenlitian ini adalah field research, yaitu penelitian yang didasarkan pada studi sebuah kasus. Ciri pokok dalam jenis penelitian ini adalah keterlibatan peneliti di lapangan untuk menghayati berbagai pola pikir dan aktivitas subyek penelitian (Muhajir, 1998: 13). Penelitian ini menggunakan data primer dengan cara menggali informasi seputar masalah penghimpunan dan pendistribusian zakat produktif. Dengan demikian, subyek penelitian ini adalah para pengurus BAZIS Pulosari, muzakki dan mustahiq.

Adapun tehnik pengumpulan data dilakukan dengan tiga cara. Pertama, pengamatan (observasi) yaitu pengamatan yang digunakan untuk memperoleh informasi mengenai gejala-gejala yang dalam kehidupan sehari-hari. Hasil pengamatan yang terkumpul kemudian didiskusikan dengan warga masyarakat yang bersangkutan untuk mengetahui makna yang terdapat di balik gejala-gejala atau peristiwa yang terjadi. Kedua, mewancarai dengan tokoh lembaga atau para fungsionaris khususnya pihak manajemen BAZIS Dusun Jumoyo yang berkompeten dan representatif untuk memperoleh informasi mengenai penghimpunan zakat dan pendistribusian model produktif. Ketiga, Dokumentasi. Tehnik ini dilakukan untuk mengeksplorasi data sekunder yang dikumpulkan melalui media

off line maupun on line, arsip, dokumen dan referensi lainnya yang terkait dengan topik ini (Creswell, 2002: 20-221).

Semua data yang terkumpul melalui pengamatan, wawancara dan dokumen dipilah berdasarkan kelompok tema. Selanjutnya data-data yang telah dikategorikan diinterpretasikan dengan model surface structure kemudian dikembangkan ke interpretasi deep structure. Interpretasi kedua ini ini untuk mengungkap makna-makna tersirat di balik penjelasan sumber informasi maupun aktivitas para pengurus BAZIS Dusun Pulosari, muzakki dan mustahiq. Untuk mengurangi ketidaksahihan data, maka dilakukan kritik dengan cara crosschek data untuk memperoleh akurasi kebenaran yang bisa dipertanggungjawabkan. 


\section{Analisis}

Kemunculan dan Perkembangan BAZIS di Dusun Pulosari

Zakat yang selama ini dipahahami pemanfaatannya hanya sebatas keperluan konsumtif telah dimaknai untuk kepentingan peningkatan kesejahteraan hidup yang lebih luas. Menyikapi masalah itu, masyarakat dusun Pulosari Desa Jumoyo, Kecamatan Salam, Kabupaten Magelang yang berada di lereng Gunung Merapi me ncoba mewujudkan pengelolaan zakat untuk usaha produktif dalam rangka membantu mensejahterakan kaum kurang mampu (dhuafa' dan mustad'afin). Rintisan pengelolaan zakat di Pulosari dirintis tahun 2000 oleh keluarga besar Bapak Joko. Mereka merasa punya penghasilan cukup sementara di sisi lain ada banyak tetangga yang hidup kekurangan. Lima anggota keluarga Joko kemudian sepakat menyisihkan gaji untuk dizakatkan. Dana itu digunakan untuk menyantuni fakir miskin serta membantu pendidikan siswa kurang mampu. Lama kelamaan, banyak tetangga mereka yang ikut menitipkan uang.

Setelah lima tahun warga yang ikut berzakat semakin besar. Pada November 2005, warga Dusun Pulosari sepakat membentuk BAZIS untuk menangani zakat masyarakat. Meskipun namanya Baziz, tetapi tidak terstruktur di pemerintahan desa dan lembaga ini murni dikelola oleh swasta. Bulan pertama terkumpul dana Rp 780.000. Bulan sama tahun 2007 Rp 27 juta, lalu Rp 52 juta (2008), Rp 73 juta (2009), Rp 58 juta (2010) dan tahun 2011 menembus Rp 96 juta. Tahun 2010 anjlok drastis karena ada erupsi dan banjir lahar Gunung Merapi. Ketika itu ratusan warga Desa Jumoyo termasuk Pulosari kehilangan harta benda, rumah, dan usaha. Dampaknya, penarikan zakat berhenti total selama sekitar delapan bulan. Panitia tidak tega menarik zakat ke warga yang tengah dirundung bencana akibat banjir lahar. Pada tahun 2011 zakat mulai ditarik lagi, jumlahnya melonjak menjadi Rp 96 juta. Kini setelah tujuh tahun pengelolaan zakat dilembagakan, setoran bulanan mereka mencapai kisaran Rp 8 jutaan dan saldo Rp 50 juta. Selain digunakan untuk menyantuni fakir miskin, bantuan biaya kesehatan, dan pendidikan warga tidak mampu, dana zakat juga digunakan untuk memakmurkan masjid dan mushola. Menurut Badruz Zaman, ketua Badan Amil Zakat 
dan Sodakoh (BAZIS) Pulosari, bahwa pihaknya pun telah berhasil mengembangkan usaha ekonomi produktif. Ada banyak usaha yang dimodali dana zakat ini seperti usaha jamur, perikanan, jualan sayuran (eyek), hingga kandang terpadu kambing dan sapi.

\section{Profil Muzakki dan Mustahiq di BAZIS Dusun Pulosari}

Muzakki BAZIS Pulosari adalah seluruh warga Pulosari maupun sekitarnya yang memenuhi kritria sebagai muzakki. Jenis pekerjaan penduduk Pulosari bervariasi seperti PNS, buruh harian lepas, buruh tani, petani, tukang batu, karyawan swasta, wiraswasta. Nominal pembayaran kecil umumnya mereka yang berprofesi sebagai PNS, sedangkan mereka yang memiliki profesi bisnis memiliki kemampuan bayar zakat cukup tinggi. Ketentuan nisab sebagaimana diatur dalam kitab zakat diserahkan pada pribadi muzakki, artinya penilaian kepantasan sangat subyektif. Di samping muzakki individual, juga terdapat muzakki kelompok, yaitu kelompok ternak yang dulu pernah diberi modal dari dana zakat produktif.

Sedangkan mustahiqadalah merekayang sangatmembutuhkan dan tidak memiliki saving karena income dari pekerjaan yang sangat minim. Berdasarkan pekerjaan yang berpotensi menjadi mustahid di Dusun Pulosari adalah mereka yang berprofesi sebagai buruh harin, buruh tani dan tukang batu. Dari total jumlah $272 \mathrm{KK}$ sedangkan muzakki hanya 35 orang, berarti yang masuk kategori muzakki hanya $7,8 \%$.

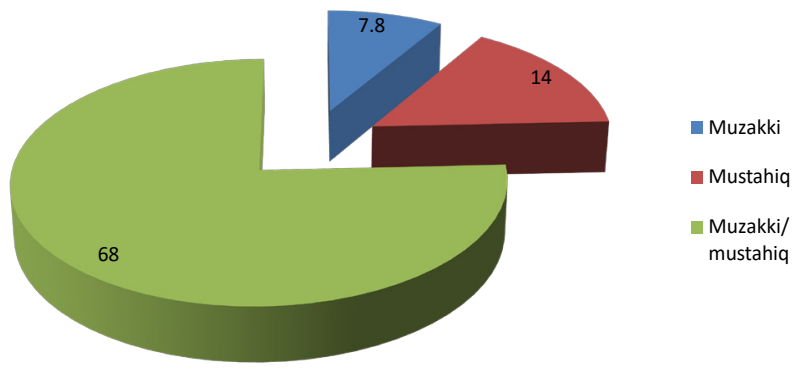

Grafik prosentase muzakki dan mustahiq di Dusun Pulosari 
Dari grafik di atas, terdapat sekolompok masyarakat (68\%) yang mungkin di posisi muzakki atau mustahiq. Hal itu dikarenakan pengurus merasa tidak memiliki kewenangan untuk melakukan survey secara mendetail. Pihak yang yang memposisikan sebagai muzakki hanya didasarkan pada kesedaran untuk membayarkan zakatnya pada BAZIS. Tetapi melihat profil pekerjaan dan pantauan peneliti di Dusun Pulosari, kelompok 68\% tersebut mayoritas adalah muzakki. Hal itu juga didukung pendapat ketua BAZIS, Badrun Zaman, adalah masalah tertentu terhadap penggurus sehingga banyak muzakki enggan atau membayar zakat di tempat yang lain. Jumlah muzakki yang membayar zakat di BAZIS sebanyak 35 orang.

\section{Pengelolaan Zakat Produktif di BAZIS Dusun Pulosari}

1. Program Pengumpulan

Pengumpulan zakat dan infaq dilaksanakan oleh Seksi Pengambilan dengan sistem jemput bola ke rumah muzaki (bulanan maupun tahunan) untuk selanjutnya disetorkan ke bendahara. Di samping itu pengurus juga menerima zakat/ infaq secara insidentil dari beberapa warga masyarakat yang mendapatkan rezeki lebih dari Allah SWT. Untuk mengetahui jumlah pengumpulan zakat mal dan rencana pentasharufannya dilakukan rapat rutin bulanan dengan tempat bergilir dari rumah ke rumah pengurus dalam rangka menjalin komunikasi dan koordinasi yang intensif demi terciptanya situasi yang harmonis baik internal maupun eksternal. Pengurus BAZIS telah melaksanakan 4 (empat) kali rapat rutin dengan agenda: 1) Menyusun Program Kerja; 2) Laporan Keuangan; 3) Rapat Menyusun Rencana Pentasyarufan; 4) Evaluasi pelaksanaan program yang telah dilaksanakan.

Pada tahun 2010 penerimaan zakat anjlok drastis karena ada erupsi dan banjir lahar Gunung Merapi. Ketika itu ratusan warga Desa Jumoyo termasuk Pulosari kehilangan harta benda, rumah, dan usaha. Dampaknya, penarikan zakat berhenti total selama sekitar delapan bulan. Panitia tidak tega menarik zakat ke warga yang tengah dirundung 
bencana akibat banjir lahar. Pada tahun 2011 zakat mulai ditarik lagi, jumlahnya melonjak menjadi Rp 96 juta. Kini setelah tujuh tahun pengelolaan zakat dilembagakan, setoran bulanan mereka mencapai kisaran Rp 8 jutaan dan saldo Rp 50 juta.

Melihat perkembangan penerimaan zakat dari tahun ke tahun, patut disayangkan karena trennya adalah menurun. Hal itu dilihat dalam tabel berikut:

\begin{tabular}{|c|c|c|c|}
\hline NO. & TAHUN & $\begin{array}{c}\text { PENERIMAAN } \\
\text { ZAKAT }\end{array}$ & $\begin{array}{c}\text { PENTASHARUFAN } \\
\text { ZAKAT }\end{array}$ \\
\hline 1. & 2006 & 17.310 .500 & 14.227 .500 \\
\hline 2. & 2007 & 13.911 .000 & 18.799 .000 \\
\hline 3. & 2008 & 36.774 .000 & 37.280 .000 \\
\hline 4. & 2009 & 50.424 .200 & 44.697 .000 \\
\hline 5. & 2010 & 37.206 .500 & 34.478 .000 \\
\hline 6. & 2011 & 55.351 .750 & 28.603 .000 \\
\hline 7. & 2012 & 19.942 .000 & 41.234 .000 \\
\hline 8. & 2013 & 20.955 .000 & 35.113 .500 \\
\hline JUMLAH & & 261.874 .950 & 254.432 .000 \\
\hline
\end{tabular}

2. Sasaran Pentasyarufan

Pentasarufan dana zakat profesi dan zakat mal lainnya di Dusun Pulosari difokuskan pada zakat produktif, tujuh program bantuan dan satu kegiatan administratif. Dari berbagai bentuk obyek pentasharrufan di atas, tulisan ini hanya akan memfokuskan pada pentasyarufan zakat untuk usaha produktif atau sering disebut zakat produktif. Berikut ditampilkan obyek bantuan dan kegiatan administrative sebagaimana dapat dilihat pada bagan berikut ini: 


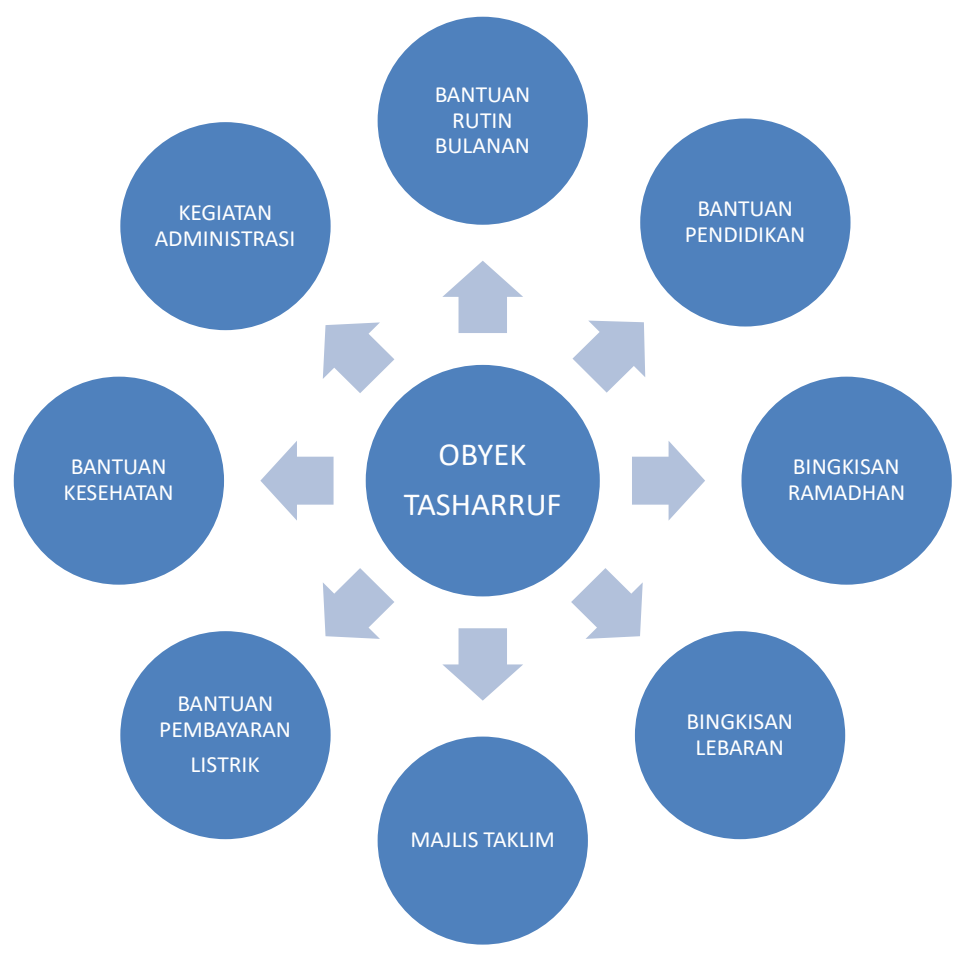

Gambar Obyek Penyaluran Zakat

3. Model Pentasharufan Zakat Produktif di Dusun Pulosari

Ketua Bazis Pulosari, Badrus Zaman mengatakan bahwa pihaknya pun telah berhasil mengembangkan usaha ekonomi produktif. Ada banyak usaha yang dimodali dana zakat ini. Mulai usaha jamu, perikanan, jualan sayuran (eyek), hingga kandang terpadu kambing dan sapi. Dari berbagai macam pentasharufan zakat produktif, maka amil melakukan tiga macam bentuk sebagaimana terpapar dalam kajian teoritik. Adapun tiga bentuk itu adalah:

a. Model in kind, yaitu pengurus BAZIS sebagai amil memberikan zakat sebagai modal tanpa harus mengembalikan kepada amil serta tanpa ikatan apun. Hal itu dilakukan oleh pengurus BAZIS dengan memberikan modal kepada pedagang individual seperti pedagang 
sayuran (eyek), jamu dan lain-lain. Model penyaluran ini dapat digambarkan berikut ini:

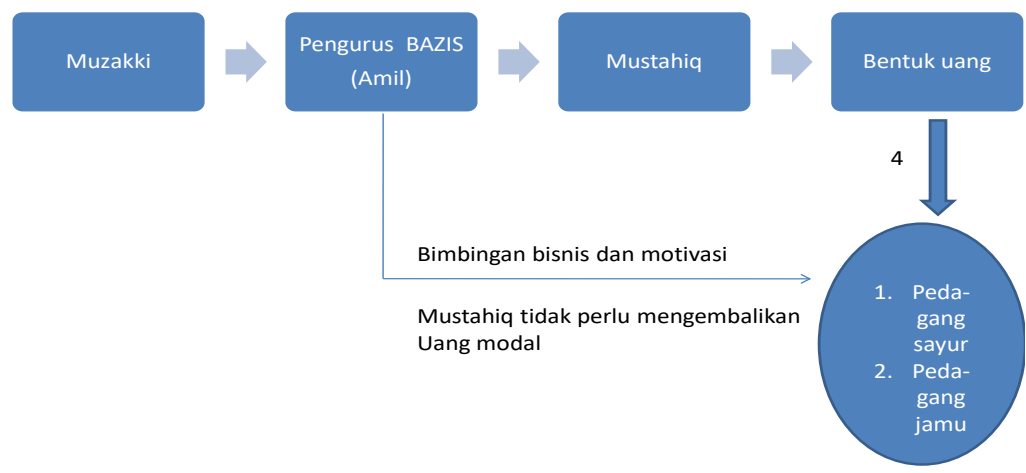

b. Model mudharabah non finansial, yaitu pengurus BAZIS selaku amil memberikan indukan kambing etawa kepada muzakki, apabila kambing beranak maka anakkannya menjadi hak mustahiq sedangkan indukannya dikembalikan kepada pengurus selaku amil untuk ditasharrufkan kepada mustahiq lainnya. Dari hanya beberapa ekor kambing, kini sudah menjadi ratusan ekor. Lebih dari 60 ekor hasil peranakan sudah dijual dan 30 ekor sisanya dijadikan indukan. Atas keberhasilan pengelolaan dana zakat untuk pengembangan kandang terpadu ini, Dusun Pulosari diberi penghargaan pemerintah pusat dana sebesar Rp 350 juta. Dana ini digunakan untuk pembangunan kandang terpadu sapi. Mereka memelihara sapi betina sebanyak 35 ekor. Kambing etawa dan sapi ini dikelola oleh kelompok peternak yang diberi nama Sido Mulyo. Mereka beranggotakan 30 orang, sebanyak 16 anggota mengembangkan budidaya sapi dan 14 lainnya kambing etawa. Kelompok juga memanfaatkan kotoran sapi untuk pembuatan pupuk organik dan biogas. Biogas digunakan untuk memasak warga, sementara kompos untuk memupuk lahan pertanian. Kelompok Sido Mulyo juga menjalin kerja sama dengan Universitas Gadjah Mada (UGM) untuk mengembangkan budidaya sapi dan 
kambing etawa. Model penyaluran ini dapat digambarkan berikut ini:

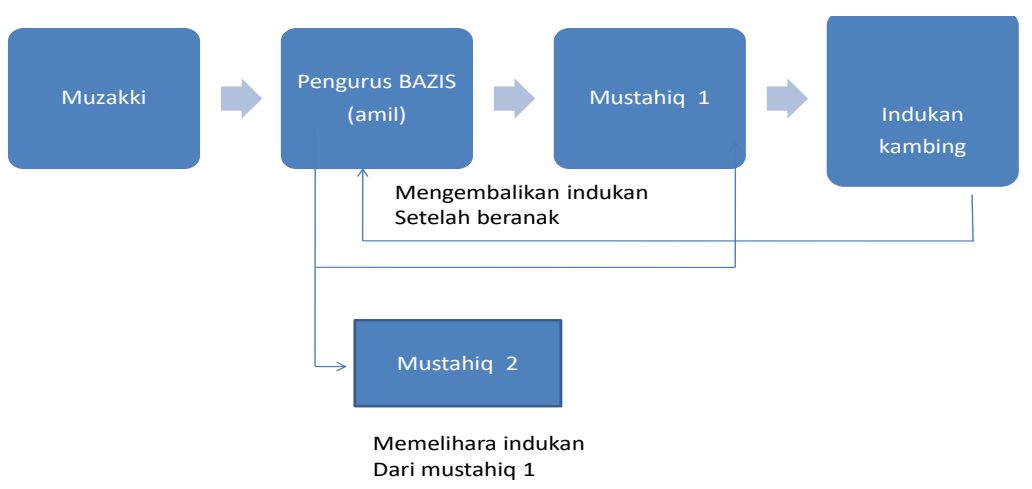

c. Model al-Qard al-Hasan finansial, pengurus BAZIS selaku amil mentasharrufkan harta zakat dalam bentuk modal kepada mustahiq untuk melakukan suatu usaha dengan ketentuan ahanya mengembalikan modal saja. Model ini diberikan kepada mustahiq secara kolektif atau kelompok untuk memelihara ikan lele dan kambing etawa. Masa angsuran juga dibebaskan, selama 2-3 tahun tergantung kemampuan kelompok usaha. Usaha budidaya lele terpal sudah berkembang, terdapat 15 anggota aktif memelihara di pekarangan rumah masing-masing. Awal rintisan usaha dilakukan secara kelompok, namun saat ini secara individual. Dari sekian banyak usaha, budidaya kambing etawa yang paling berkembang. Model penyaluran ini dapat digambarkan berikut ini:

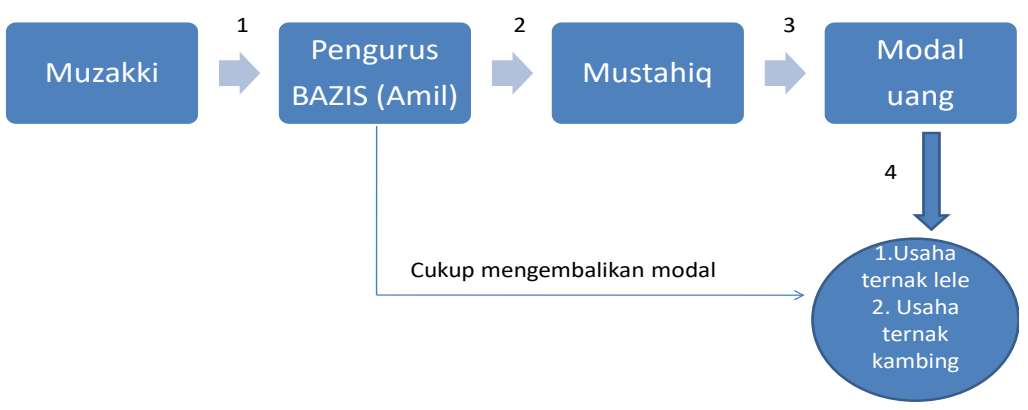




\section{Kesimpulan}

Dari pembahasan di atas dapat disumpulkan, bahwa BAZIS Dusun Pulosari, Dsa Jumoyo, Kecamatan Salam Kabupaten Magelang telah melakukan tiga bentuk pentasyarufan zakat produktif. Pertama model in kind, yaitu pengurus BAZIS sebagai amil memberikan zakat sebagai modal tanpa harus mengembalikan kepada amil serta tanpa ikatan apun. Kedua, Model mudharabah non finansial, yaitu pengurus BAZIS selaku amil memberikan indukan kambing etawa kepada muzakki, apabila kambing beranak maka anakkannya menjadi hak mustahiq sedangkan indukannya dikembalikan kepada pengurus selaku amil untuk ditasharrufkan kepada mustahiq lainnya. Ketiga, model al-Qard al-Hasan finansial. Pengurus BAZIS selaku amil mentasharrufkan harta zakat dalam bentuk modal kepada mustahiq untuk melakukan suatu usaha dengan ketentuan hanya mengembalikan modal saja.

Ketiga model tersebut apabila terus dilakukan dengan baik dan berkesinambungan, akan meningkatkan produktifitas mustabiq. Dmpak berikutnya akan mengurangi angka kemiskinan dalam masyarakat yang selanjutnya akan dapat mengurangi ketergantungan ekonomi penduduk khususnya di Dusun Pulosari. Untuk memastikan, penyaluran zakat produktif ini berjalan baik, maka seyognya pengurus BAZIS bermitra dengan konsultan di berbagai bidang seperti manajemen keuangan, pertanian, perternakan dan perikanan.

\section{Daftar Pustaka}

Ali, Muhammad Daud. 1988. Sistem Ekonomi Islam Zakat dan Wakaf, Jakarta UII Press.

Arikunto, Suharsimi. 1998. Prosedur Penelitian: Suatu Pendekatan Praktek), cet. 11, Jakarta : PT Rineka Cipta.

Asnaini. 2008. Zakat Produktif dalam Perspektif Hukum Islam, Yogyakarta: Pustaka Pelajar. 
Cholid dan Abu Achmadi. 2003. Metodologi Penelitian. cetakan 5. (Jakarta: Bumi Aksara.

Creswell, John W., Educational Research: Planning, Conducting and Evaluating Quantitative and Qualitative Research.New Jersey: Pearson Merrill Prentice Hall.

Daniel, Moehar. 2003. Metode Penelitian Sosial Ekonomi, cet.2, Jakarta: Bumi Aksara.

Hafidhuddin, Didin. 2002. Zakat Dalam Perekonomian Modern, Jakarta: Gema Insani

Kompas, 9 April 2018

Kurde, Nukhtoh Arfawie. 2005. Memungut Zakat dan Infaq Profesi, Yogyakarta: Pustaka Pelajar.

Mannan, M. Abdul. 1995. Teori dan Praktek Ekonomi Islam (Islamic Economic: Theory and Praktice), Yogyakarta: Dana Bhakti Wakaf.

Mochlasin. 2015. Community Development dengan Instrumen Zakat Profesi di Desa Jumoyo, Kecamatan Salam, Kabupaten Sleman. Inferensi. Vol 9, N0. 1 Juni.

Mufraini, Arif. 2006. Akuntansi dan Manajemen Zakat. Jakarta: Kencana.

Muhajir, Noeng. r..r. Metode Penelitian Kualitatif. Yogyakarta. Rake Sarasin

Muhamad dan Masud, Ridwan. 2005. Zakat dan Kemiskinan. Yogyakarta: UII Press.

Qaradhawi, Yusuf. Tt. Fiqh az-Zakah, Bairut: Dar al-Irsyad.

Rahman, Afzalur. 1995. Doktr in Ekonomi Islam (Economics Doctrine of Islam), Yogyakarta: Dana Bhakti Wakaf.

Soehadi. 1999. Pengantar Metodologi Penelitian Sosial Bisnis Manajemen, Yogyakarta: Lukman offset. 
Sugiono. 2007. Metode Penelitian Kuantitatif-Kualitatif dan R\&D, set. III, Bandung: Alvabeta.

-------Teologi Kemiskinan: Doktrin Dasar dan Solusi Islam atas Problem Kemiskinan (Musykilat al-Faqr wa Kaifa 'Alajaha al-Islam). Alih bahsaA. Maimun Syamsudin dan A.Wahid Hasan. Yogyakarta: Pustaka Pelajar.

Undang-undang Zakat No.23 tahun 2011.

Zuhaili, Wahbah, al-Fiqh al-Islami wa Adillatuhu, Darul Fikr, jilid II 